\title{
Spatiotemporal variability of hydrocarbons in surface sediments from an intensively human-impacted Xiaoqing River-Laizhou Bay system in the eastern China: Occurrence, compositional profile and source apportionment
}

\author{
Ding He ${ }^{\mathrm{a}, *}$, Kai Zhang ${ }^{\mathrm{a}}$, Xingqian Cui ${ }^{\mathrm{b}}$, Jianhui Tang ${ }^{\mathrm{c}}$, Yongge Sun ${ }^{\mathrm{a}}$ \\ a Institute of Environment \& Biogeochemistry (eBig), School of Earth Science, Zhejiang University, Hangzhou 310027, China \\ b Department of Earth, Atmospheric and Planetary Sciences, Massachusetts Institute of Technology, Cambridge, MA 02139, USA \\ ' Yantai Institute of Coastal Zone Research, CAS, Yantai, Shandong 264003, China
}

\section{H I G H L I G H T S}

- Anthropogenic instead of biogenic inputs were major components of hydrocarbons.

- High seasonal difference observed in aliphatic hydrocarbon composition.

- Stronger phytoplankton and microbial derived hydrocarbons observed in summer.

- No seasonal variation observed for aromatic hydrocarbon composition.
G R A P H I C A L A B S T R A C T
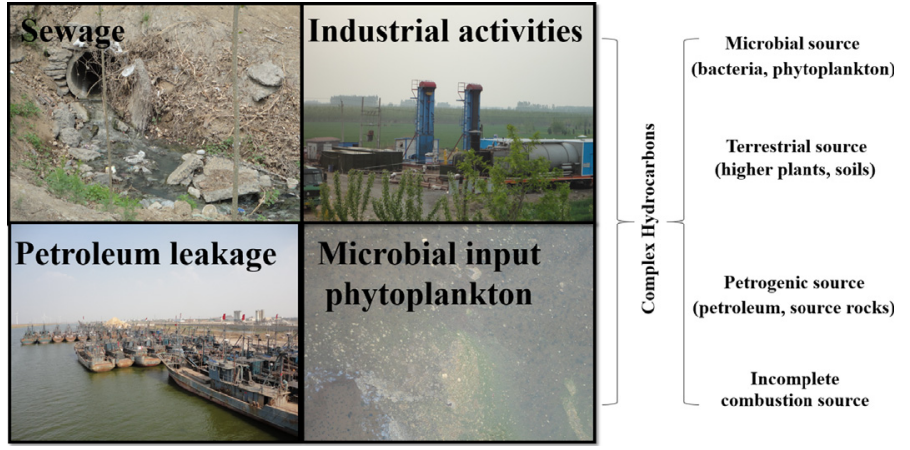

A B S T R A C T

Hydrocarbons in coastal sediments record organic matter sources, and thus are widely used to elucidate both natural and anthropogenic inputs and for the estimation of pollution levels. Surface sediments were taken from Xiaoqing River and Laizhou Bay of eastern China in spring and summer of 2014, and were analyzed to determine the characteristics of aliphatic and aromatic hydrocarbons. Various hydrocarbons were identified, including $n$ alkanes, monomethylated alkanes (MMAs), isoprenoid alkanes, linear alkylbenzenes (LABs), hopanes, steranes and polycyclic aromatic hydrocarbons (PAHs). They were used to track both biogenic (terrestrial plant and microbial inputs) and anthropogenic inputs (petroleum and fossil fuel or biomass burning) in this ecosystem. The major part of hydrocarbons identified came from anthropogenic inputs including petroleum residues and synthetic detergents related hydrocarbons (16.2-90.3\%), followed by higher plant (4.5-80.5\%) and microbial inputs (0.8-57.5\%). Interestingly, significant differences in hydrocarbon concentrations and distributions were observed between spring and summer. In particular, significant higher percentages of microbially derived hydrocarbons, but lower percentages of anthropogenic and vascular plant derived hydrocarbons were observed in summer than spring. Further principal component analyses suggested that the overall distribution of aliphatic hydrocarbons was mainly controlled by seasonality instead of spatiality. In contrast, the distribution of PAHs showed insignificant spatial and seasonal differences. Physical processes such as atmospheric transportation and further deposition, may be factors influencing the distribution of PAHs in the study area with widely biomass and fossil fuel burning. The decoupled distributions of aliphatic and aromatic hydrocarbons warrant further study for a

\footnotetext{
* Corresponding author.

E-mail address: dinghe@zju.edu.cn (D. He).
} 
comprehensive understanding of long term sedimentary hydrocarbon sources and input dynamics with increasing human activities.

Major finding: Seasonal difference in aliphatic hydrocarbon composition was observed in surface sediments of Laizhou Bay, which is mainly caused by stronger phytoplankton and microbial inputs in summer under the overall high pollution background.

(c) 2018 Elsevier B.V. All rights reserved.

\section{Introduction}

Coastal areas receive tremendous amount of natural and anthropogenic organic matter (OM) from land through river transport (Canuel and Hardison, 2016). Hydrocarbons, as an important component of $\mathrm{OM}$, have received great attention since they adsorb onto particles, settle and accumulate in surface sediments, making surface sediments an important pool of hydrophobic contaminations (e.g., Volkman et al., 1992; Commendatore et al., 2012; Shirneshan et al., 2016). During resuspension and remobilization, hydrocarbons can be released from sediments into the overlying water, resulting in secondary pollution in the coastal environment (Gobas and MacLean, 2003; Dong et al., 2016).

Hydrocarbon composition and concentration impact the biodiversity and biogeochemistry of the coastal environment (Harris et al., 2011; Canuel and Hardison, 2016). Therefore, the determination of hydrocarbon composition and source is crucial in further protecting ecological environment and human health (e.g., Birgel et al., 2004; Rushdi et al., 2006). Natural coastal ecosystems have a large proportion of hydrocarbons derived from biogenic sources, such as vascular plants and microbes (e.g., Medeiros et al., 2005; Bajt, 2012). Additionally, petroleum and its derivatives carried by rivers are another contributor of hydrocarbons (e.g., Zheng and Richardson, 1999). The latter ones, sometimes, are a major source of hydrocarbons in coastal environments owing to severe anthropogenic influences such as waste water discharges, shipping activities, offshore oil production and transport, as well as fossil fuel combustion from industrial processes (Wakeham, 1996). Overall, hydrocarbons in coastal sediments are detected as complex mixtures including aliphatic and aromatic hydrocarbons deriving from multiple sources (Medeiros et al., 2005; Bianchi and Canuel, 2011). Therefore, the determination and differentiation of hydrocarbons between natural and anthropogenic sources are crucial for environmental health evaluation and require the application of multiple reliable indicators (Bianchi and Canuel, 2011; Peters et al., 2005).

With the development of analytical tools in the last several decades, numerous organic biomarkers were established to fingerprint the origin and cycling of hydrocarbons (Bianchi and Canuel, 2011). For example, aliphatic hydrocarbons are widely applied to separate natural (e.g., leaf waxes) from anthropogenic inputs (e.g., petroleum and derivatives) (Eglinton and Hamilton, 1967; Yunker et al., 2002; Commendatore et al., 2012). Hopanes and steranes are commonly used as indicators of petroleum contaminations (Aboul-Kassim and Simoneit, 1996; Shirneshan et al., 2016). Linear alkylbenzenes (LABs), a series of compounds that have been added in the manufacture of commercial detergents since 1960s, can serve as an exclusive indicator of domestic waste inputs through fluvial transport (e.g., Takada and Ishiwatari, 1987; Medeiros et al., 2005). Polycyclic aromatic hydrocarbons (PAHs), a class of persistent organic pollutants commonly found in coastal environments, are usually related to (i) pyrolytic sources, such as vehicle and other exhaust emissions, the burning of biomass, petroleum and its derivatives; (ii) petrogenic sources, such as effluents from oil refineries and small oil spills by shipping traffic; and (iii) less contributions from natural sources (diagenetic origin), including the post depositional transformation of biogenic precursors (Yunker et al., 2002). The application of the multi-biomarkers has allowed a better understanding of both natural and anthropogenic inputs of OM in the highly productive coastal environment (Pisani et al., 2013).
Due to rapid industrial and economic development, Chinese marginal seas have been affected severely by anthropogenic activities, such as fossil fuel combustion, petroleum spills, and sewage contaminations (Zhang et al., 2010; Liu et al., 2012). A typical example is the Laizhou Bay, a semi-closed bay within the Bohai Sea. The Xiaoqing River, with a length of ca. $240-\mathrm{km}$, is the second longest river draining into the Laizhou Bay, only secondary to the Yellow River. However, in contrast to the Yellow River that is dominated by natural OM (Tao et al., 2015), the Xiaoqing River is a major source of organic pollutants to the Laizhou Bay owing to significant anthropogenic inputs, such as industrial and manufacturing related inputs and waste water from several large cities and agricultural non-point sources (Jiang et al., 2017). In addition, the Bohai Bay Basin is known for its petroleum source beds, which could be another hydrocarbon source to the Xiaoqing River and Laizhou Bay (Pang et al., 2003). With relatively small water exchange, low tidal effects and high sedimentation rates (Li et al., 2012), fast accumulation of pollutants was detected in the Laizhou Bay (Zhang et al., 2009).

Most studies on organic compositions in surface sediments from the Laizhou Bay, to date, have focused primarily on crude oil pollution or specific pollutants such as organochlorine pesticides, perfluoroalkyl acids (PFAAs), polychlorinated naphthalenes (PCNs) and polybrominated diphenyl ethers (PBDEs) (Pan et al., 2011; Zhong et al., 2011; Zhao et al., 2013), whereas few studies have investigated sources of hydrocarbons comprehensively. Although some recent studies have examined hydrocarbon compositions in the Laizhou Bay, few of them have linked the hydrocarbon in the Laizhou Bay to its adjacent rivers (Liu et al., 2009; Hu et al., 2009, 2011; Wang et al., 2015). It largely limits our knowledge on the sources and transformation of hydrocarbons along the river-toestuary transect. In addition, temporal variation of hydrocarbon composition and concentration is an important indicator of environment health in coastal zones, but it has usually been studied over decadal or centurial scales (e.g., Hu et al., 2011). So far, the seasonal variation of hydrocarbon concentration and composition has been reported in typical large river-estuary systems with high sedimentation rates. For instance, both concentrations and sources of PAHs varied seasonally in the surface sediments of the Yangtze River estuary (Yu et al., 2016). However, study on the variation of the overall composition and concentration of hydrocarbon along an anthropogenically disturbed river-estuary system is lacking on a seasonal scale. In this respect, this work is based on a suite of surface sediments collected from the Xiaoqing River and the Laizhou Bay and focused on multiple geochemical markers including $n$-alkanes, isoprenoid alkanes (pristine and phytane), monomethylated alkanes (MMAs), hopanes, steranes, LABs, unresolved complex mixtures (UCM) and PAHs. Several relevant proxies are also calculated to discriminate natural from anthropogenic hydrocarbon inputs. The purposes are to (i) assess both spatial and seasonal variations of hydrocarbons, and (ii) evaluate the possible sources and dynamics of these hydrocarbons and its linkages with human activities in the drainage basin.

\section{Methods and materials}

\subsection{Study area and sampling}

Two field sampling trips were performed in spring (early April) and summer (late August) of 2014. Sampling sites were selected to provide 
a wide spatial coverage of the Xiaoqing River to Laizhou Bay system (Fig. 1, Table S1; He et al., 2018). In total, 33 surface (top ca. $4 \mathrm{~cm}$ ) sediment samples were collected. Spatially and temporally, these samples were divided into three groups, including samples obtained from upstream of the Xiaoqing River in spring $(\times 1$ to $\times 11)$, samples obtained from the Laizhou Bay in spring (L1sp to L11sp) and summer (L1su to L11su), respectively (Fig. 1). Upon collection, each sample was wrapped in pre-cleaned alumina foil and stored frozen at $-20^{\circ} \mathrm{C}$. Before extraction, $10 \mathrm{~g}$ of each was subsampled, freeze dried, homogenized and sieved to obtain the $<125 \mu \mathrm{m}$ fraction.

\subsection{Sample preparation and analysis}

The bulk parameters, including sediment grain size, bulk total organic carbon (TOC) and $\delta^{13} \mathrm{C}_{\mathrm{org}}$, were measured following the method described previously (Y. He et al., 2013, 2015a,c) and were detailed in a previous study (He et al., 2018; Table S1). For the hydrocarbon analysis, all sediment samples were Soxhlet extracted using dichloromethane and methanol $(2: 1 ; \mathrm{v}: \mathrm{v})$. The extractions were concentrated to almost dryness using a gentle stream of ultra-high purity nitrogen gas. After redissolved in $n$-hexane, the extractions were then fractionated into

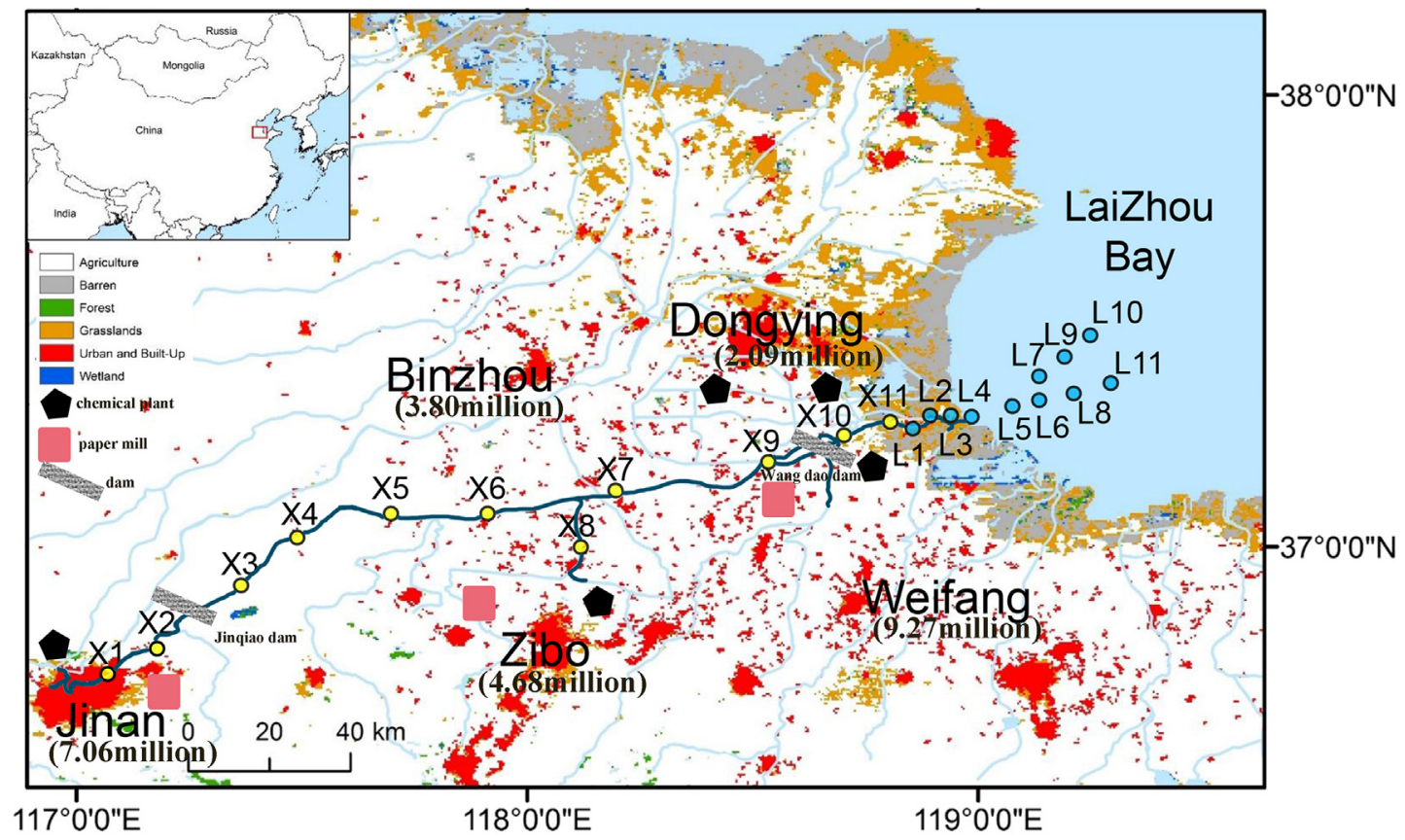

(a)

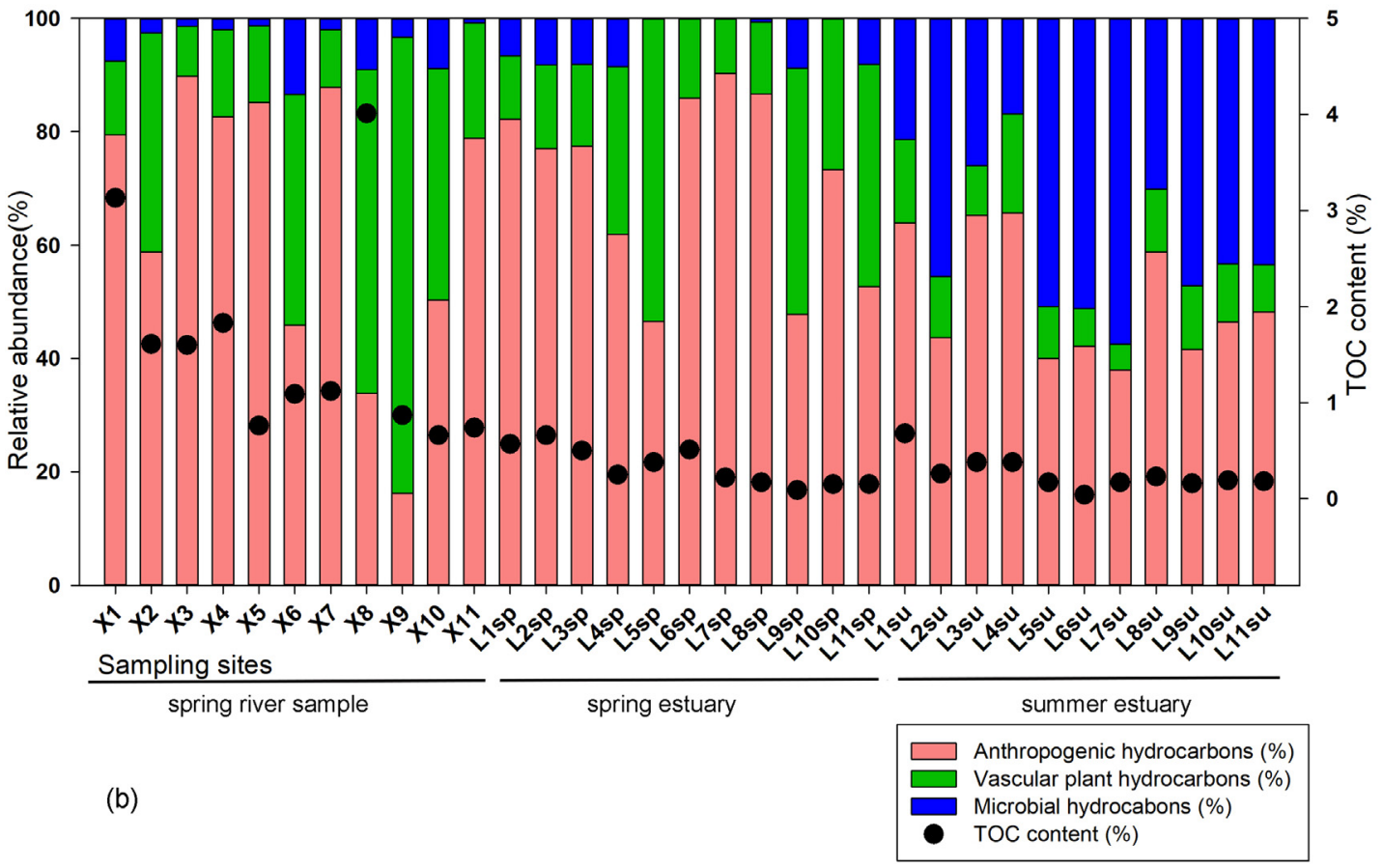

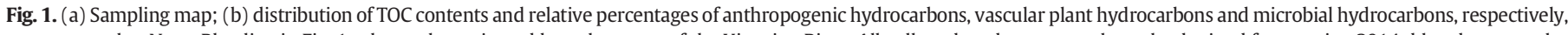

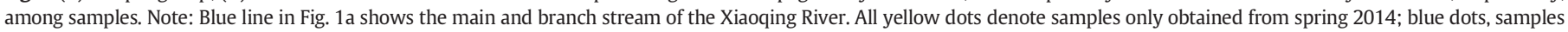
obtained in both spring and summer of 2014; the number below each city name is the population size of each city. 
saturated and aromatic hydrocarbon fractions following a method described previously (D. He et al., 2014). Each fraction was further concentrated before gas chromatography mass spectrometry (GC-MS) analysis. Briefly, the GC-MS analysis was carried out on an Agilent 7890 gas chromatographer coupled to a 5977 Mass Selective Detector. A DB-1MS fused silica capillary column $(60 \mathrm{~m} \times 0.25 \mu \mathrm{m}$ i.d. $)$ was used with helium as the carrier gas (D. He et al., 2016a,b). The GC oven temperature was programmed from $60{ }^{\circ} \mathrm{C}$ ( 2 min hold ) to $310{ }^{\circ} \mathrm{C}$ at the $6{ }^{\circ} \mathrm{C} \mathrm{min}{ }^{-1}$ ramp rate and held for $30 \mathrm{~min}$. The MS was operated in the electron impact mode with ion source energy of $70 \mathrm{eV}$. In order to cover a large scope of hydrocarbon compounds, full scan was used for the GC-MS analysis in this study.

\subsection{Identification, quantification, quality assurance and quality control $(\mathrm{Q} A / \mathrm{QC})$}

The identification of $n$-alkanes, hopanes, steranes, LABs, PAHs was based primarily on GC retention times, their key ion patterns, mass spectra (i.e., fragmentation patterns) and the comparison with NIST 2008 library. MMAs were identified following the elution order and fragmentation patterns as previously described (D. He et al., 2015a, 2015b). All compounds were quantified relative to the internal standards: $C_{36} n$-alkane-d10 for alkanes, hopanes, steranes and LABs; and phenanthrene-d10, benzo(e)pyrene-d10 and coronene-d10 for PAHs, assuming similar responses (D'Anjou et al., 2012; D. He et al., 2014). The internal calibration method based on six-point calibration curves was used for the quantification of individual aliphatic and aromatic hydrocarbon in sediment samples.

Although surrogate was not spiked prior to extraction for each sample, mean recoveries of the compounds spiked into samples $\times 1$ and L1 were $>88 \%$ for $C_{36} n$-alkane-d 10 and $>84 \%$ for benzo(e)pyrene. In addition, based on a triplicate analysis of sample L1, the standard deviations of most hydrocarbon concentrations were $<15 \%$ (D. He et al., 2014). The reported concentration of each compound identified in this study was not recovery-corrected and thus considered as semi-quantitative. The detection limits of this study were $1.5-3.3 \mathrm{ng} / \mathrm{g}$ dry weight (ng/gdw) for aliphatic hydrocarbons and $0.7-2.9 \mathrm{ng} / \mathrm{gdw}$ for PAHs based on a 10 -g sample (L1sp). The UCM concentration was also semiquantitatively determined by integrating the total GC area with subtraction of the resolved peaks and using the average response factor of $C_{36}$ $n$-alkane-d10 during the instrumental calibration. No background contamination from laboratory processing was observed using procedural blanks. The concentration of each individual hydrocarbon and UCM was presented and abbreviated in Tables S2-S4.

\subsection{Biomarkers and related proxies}

In this study, the sums of the total $n$-alkanes, MMAs, PAHs, hopanes, LABs and steranes were defined as $\sum n$-alkanes, $\sum$ MMAs, $\sum$ PAHs, $\sum$ hopanes, $\sum$ LABs, and $\sum$ steranes, respectively. The homologues of biogenic $n$-alkanes were found in the range of 11 to 37 carbons. In general, short-chain $n$-alkanes $\left(<C_{20}\right)$ are produced by algae/bacteria (Volkman et al., 1992), whereas long-chain $n$-alkanes $\left(>C_{25}\right)$ are derived from higher plants (Eglinton and Hamilton, 1967). Based on this difference, a series of well-established $n$-alkane based proxies were calculated to assess hydrocarbon sources. These proxies included the low molecular weight to high molecular weight ratio (LMW/HMW), terrigenous/aquatic ratio (TAR), carbon preference indices (CPI), average chain length $(\mathrm{ACL})$, and odd even carbon number predominance (OEP) (Brassell and Eglinton, 1980; Volkman et al., 1992; Prahl et al., 1994; Aboul-Kassim and Simoneit, 1996; Meyers, 1997; Commendatore et al., 2000; Pearson and Eglinton, 2000; Yunker et al., 2002; Peters et al., 2005; Wang et al., 2006; Hu et al., 2009; Silva et al., 2012; Ranjbar Jafarabadi et al., 2017). The detailed description of each $n$-alkane based proxy will be detailed in Section 3.2. In addition to $n$ alkanes, hopanes, LABs, steranes and PAHs were mainly used to differentiate anthropogenic inputs (Yunker et al., 2002; Medeiros et al., 2005).

\subsection{Statistical analyses}

The statistical platform R3.1.1 was used for statistical analysis. Significant differences of biomarker concentrations and biomarker related ratios among different groups of samples were estimated based on Student's $t$-test, and a $P$ value of $<0.05$ was considered as statistical significance. To explore the significance of variables that elucidate the potential groupings and patterns of the inherent properties of the whole dataset, principal component analysis (PCA) with varimax normalized rotation was performed.

\section{Results and discussion}

\subsection{Bulk parameters: grain size, TOC and $\delta^{13} C_{\text {org }}$}

The surface sediments were predominantly composed of silt (40.9\% to $77.8 \%$; Table S1), denoting generally weak hydrodynamic conditions in the study region. The highest sand content (53.0\%) was observed at station L5 in spring, suggesting relatively intense waves and tidal currents close to the Xiaoqing River mouth. However, in general, no spatial trend was observed for clay, silt or sand contents. The TOC contents showed a large range from $0.04 \%$ (L6) to $4.01 \%$ ( $\times 8$; Table S1), generally reflecting different inputs of $\mathrm{OM}$, hydrodynamic sorting processes, and possibly post-depositional biodegradation (Meyers, 2003). The $\delta^{13} \mathrm{C}_{\mathrm{org}}$ values ranged from $-26.2 \%$ o to $-22.6 \%$, $-25.5 \%$ o to $-22.1 \%$, and $-26.7 \%$ o to $-25.0 \%$ for the Lsp, Lsu and X samples, respectively. Since $\delta^{13} \mathrm{C}$ values of typical $C_{3}$ plants from Chinese Loess Plateau, fresh phytoplankton, microbial biomass and marine OM were $-27.1 \pm 2.4 \%$, -29 to $-23 \%$, -18.9 to $-26 \%$, and $-20.0 \pm 1.0 \%$ (McCallister et al., 2004 ; Liu et al., 2005; Zhang et al., 2007), respectively, the $\delta^{13} C_{\text {org }}$ values observed in this study suggested OM inputs from mixed (e.g., terrestrial and marine) sources (Zhang et al., 2007). A general increase of $\delta^{13} \mathrm{C}_{\mathrm{org}}$ values and a decrease of TOC contents were observed at stations with higher surface water salinity (or spatially the Xiaoqing River to the Laizhou Bay), indicative of a natural gradient where terrestrial OM generally decreased when gradually being dominated by marine environment (Zhang et al., 2007; He et al., 2018).

\subsection{Spatiotemporal variability of hydrocarbon biomarkers}

Examples of GC chromatograms with main features and major hydrocarbons (e.g., $n$-alkanes, MMAs, hopanes, steranes, UCM and PAHs) were shown in Figs. S1 and S2. Source identification of detected biomarkers (both anthropogenic and natural sources) were conducted based on reported chemical markers and diagnostic indices from related literatures (e.g., Peters et al., 2005; Bianchi and Canuel, 2011 and references therein).

\subsubsection{Spatiotemporal variability of aliphatic hydrocarbons}

The total $n$-alkane concentrations ranged from 3300 to 34,000, 1300 to 41,000 , and 5600 to $25,000 \mathrm{ng} / \mathrm{gdw}$ for $\mathrm{X}$, Lsp and Lsu samples (Fig. S3). These wide ranges may be caused by the complexity of this environment in terms of hydrocarbon sources, cycling, sedimentation and microbial degradation processes (Kostka et al., 2011; Wang et al., 2015). The lowest total $n$-alkane concentration was observed at station L11sp, which is the farthest from the Xiaoqing River mouth, whereas the highest total $n$-alkane concentration was found at station L1sp located in the Yangkou harbor, pointing to a possible source from intensive ship traffics and occasional oil spills from vessels (Table 1; Table S3; also see Section 3.2.2). Although no clear spatial pattern was observed among the $\mathrm{X}$ and Lsu samples, a spatial decrease in $n$-alkane concentrations was observed from L1sp to L11sp in spring. 
Table 1

Typical biomarker concentration and biomarker related parameters among the X, Lsp and Lsu samples, respectively.

\begin{tabular}{|c|c|c|c|c|c|c|c|c|c|}
\hline \multirow{2}{*}{$\frac{\text { Sampling station }}{\text { Parameters }}$} & \multirow{2}{*}{$\frac{\mathrm{X} \text { samples }}{\text { Range }}$} & \multicolumn{2}{|l|}{$\mathrm{n}=11$} & \multirow{2}{*}{$\frac{\text { Lsp samples }}{\text { Range }}$} & \multicolumn{2}{|l|}{$\mathrm{n}=11$} & \multirow{2}{*}{$\frac{\text { Lsu samples }}{\text { Range }}$} & \multicolumn{2}{|l|}{$\mathrm{n}=11$} \\
\hline & & Mean & SD & & Mean & SD & & Mean & SD \\
\hline$\sum n$-Alkane (ng/gdw) & $3300-35,000$ & 13,000 & 8500 & $1300-41,000$ & 10,000 & 14,000 & $5600-25,000$ & 13,000 & 8600 \\
\hline$\sum n$-Alkanes ${ }_{25-37}(\mathrm{ng} / \mathrm{gdw})$ & $1763-27,869$ & 9712 & 7092 & $912-16,321$ & 4887 & 5166 & $689-10,712$ & 3256 & 2976 \\
\hline LMW/HMW n-alkane ratio & $0.02-0.49$ & 0.20 & 0.16 & $0.05-0.78$ & 0.29 & 0.26 & $1.0-8.3$ & 3.4 & 2.1 \\
\hline$\sum$ MMAs (ng/gdw) & $120-3300$ & 1200 & 1100 & $<$ LD-8200 & 1800 & 2900 & $2700-32,000$ & 9500 & 8100 \\
\hline$\sum$ MMAs LMW (ng/gdw) & $<$ LD-2200 & 890 & 830 & $<$ LD-5700 & 1200 & 1900 & $2200-25,000$ & 7900 & 6200 \\
\hline$\sum$ MMAs HMW (ng/gdw) & $<$ LD-1800 & 340 & 580 & $<$ LD-2400 & 590 & 960 & $62-7200$ & 1600 & 2000 \\
\hline LMW/HMW MMAs ratio & $0-15$ & 6.1 & 5.6 & $1.4-2.9$ & 2.1 & 0.56 & $3.2-110$ & 15 & 31 \\
\hline $\operatorname{Pr}(\mathrm{ng} / \mathrm{gdw})$ & $16-910$ & 430 & 250 & $10-4200$ & 900 & 1400 & $190-1200$ & 560 & 390 \\
\hline $\mathrm{Ph}$ (ng/gdw) & $43-1100$ & 650 & 350 & $24-5600$ & 1300 & 1900 & $410-2700$ & 1100 & 750 \\
\hline $\mathrm{Pr} / \mathrm{Ph}$ ratio & $0.38-0.89$ & 0.63 & 0.16 & $0.30-0.90$ & 0.66 & 0.19 & $0.35-0.81$ & 0.54 & 0.13 \\
\hline $\mathrm{CPI}_{11-37}$ & $1.3-2.1$ & 1.8 & 0.21 & $1.4-2.9$ & 1.9 & 0.52 & $0.99-1.9$ & 1.3 & 0.26 \\
\hline High $\mathrm{CPI}_{24-35}$ & $1.9-3.3$ & 2.4 & 0.49 & $1.4-4.5$ & 2.6 & 1.0 & $2.6-6.3$ & 4.5 & 1.5 \\
\hline Low $\mathrm{CPI}_{11-22}$ & $0.71-1.3$ & 0.92 & 0.15 & $0.79-1.4$ & 1.0 & 0.18 & $0.84-1.1$ & 0.94 & 0.06 \\
\hline $\mathrm{ACL}_{27-33}$ & $28.8-29.7$ & 29.4 & 0.28 & $29.1-29.8$ & 29.5 & 0.25 & $29.5-29.9$ & 29.8 & 0.13 \\
\hline TAR & $2.4-76.8$ & 14.6 & 21.2 & $1.2-28.4$ & 9.7 & 9.0 & $0.2-1.6$ & 0.58 & 0.44 \\
\hline $\mathrm{OEP}$ & $0.9-1.4$ & 1.2 & 0.14 & $1.1-1.4$ & 1.2 & 0.09 & $1.1-1.5$ & 1.3 & 0.16 \\
\hline $\operatorname{PLK}_{n \text {-alkane }}(\mathrm{ng} / \mathrm{gdw})$ & $380-1600$ & 820 & 420 & $66-9500$ & 1900 & 3300 & $430-12,000$ & 4200 & 3000 \\
\hline $\operatorname{TRE}_{n \text {-alkane }}(\mathrm{ng} / \mathrm{gdw})$ & $1400-9700$ & 7300 & 5300 & $820-14,000$ & 4000 & 4600 & $170-8400$ & 2800 & 2400 \\
\hline PETRO $_{n \text {-alkane }}(\mathrm{ng} / \mathrm{gdw})$ & $120-2100$ & 860 & 560 & $68-7600$ & 1500 & 2600 & $460-14,000$ & 4500 & 3600 \\
\hline$\sum$ Hopanes (ng/gdw) & $240-18,000$ & 6300 & 4700 & $320-25,000$ & 7100 & 9900 & $150-13,000$ & 2800 & 3800 \\
\hline $\mathrm{T}_{\mathrm{s}} / \mathrm{T}_{\mathrm{m}}$ ratio & $0.75-1.0$ & 0.82 & 0.08 & $0.74-0.95$ & 0.79 & 0.06 & $0.66-1.2$ & 0.87 & 0.13 \\
\hline $\mathrm{C}_{31} \mathrm{~S} /(\mathrm{S}+\mathrm{R})$ ratio & $0.54-0.59$ & 0.57 & 0.02 & $0.55-0.59$ & 0.58 & 0.01 & $0.54-0.59$ & 0.57 & 0.02 \\
\hline $\mathrm{C}_{27}$ steranes (ng/gdw) & $38-950$ & 430 & 280 & $19-2500$ & 670 & 990 & $10-1300$ & 240 & 400 \\
\hline $\mathrm{C}_{28}$ steranes (ng/gdw) & $41-630$ & 380 & 200 & $23-2500$ & 620 & 890 & $13-1.100$ & 220 & 330 \\
\hline $\mathrm{C}_{29}$ steranes (ng/gdw) & $52-820$ & 540 & 280 & $37-2900$ & 830 & 1200 & $17-1.500$ & 320 & 470 \\
\hline$\sum$ Steranes (ng/gdw) & $130-2400$ & 1400 & 730 & $78-7400$ & 2100 & 3100 & $40-400$ & 790 & 1200 \\
\hline $\mathrm{C}_{27} / \mathrm{C}_{29}$ sterane & $0.48-1.2$ & 0.75 & 0.19 & $0.51-1.1$ & 0.72 & 0.16 & $0.55-0.87$ & 0.68 & 0.10 \\
\hline$\beta$-Carotane (ng/gdw) & $<\mathrm{LD}-780$ & 220 & 250 & $<\mathrm{LD}-780$ & 220 & 310 & $<\mathrm{LD}-160$ & 70 & 70 \\
\hline LABs (ng/gdw) & $92-2300$ & 670 & 630 & $27-2700$ & 680 & 980 & $30-1100$ & 340 & 360 \\
\hline UCM (ng/gdw) & $4400-99,000$ & 51,000 & 29,000 & $4700-250,000$ & 74,000 & 98,000 & $11,000-130,000$ & 49,000 & 43,000 \\
\hline$\sum 21$ PAHs (ng/gdw) & $970-32,000$ & 8800 & 8700 & $67-51,000$ & 8400 & 14,000 & $95-10,000$ & 3600 & 3200 \\
\hline$\sum 3$ ring $\mathrm{PAHs}(\%)$ & $15.0-31.1$ & 24.2 & 5.8 & $0-41.9$ & 22.8 & 0.11 & $16.3-38.8$ & 26.1 & 7.7 \\
\hline$\sum 4$ ring PAHs (\%) & $42.5-69.2$ & 54.3 & 8.3 & $44.1-53.9$ & 49.2 & 0.04 & $41.7-54.4$ & 48.5 & 3.5 \\
\hline$\sum 5$ ring PAHs (\%) & $10.5-29.8$ & 18.2 & 6.0 & $11.4-39.5$ & 24.4 & 0.08 & $11.2-27.8$ & 22.1 & 5.0 \\
\hline$\sum 6$ ring PAHs (\%) & $0-10.4$ & 3.1 & 3.3 & $1.2-6.5$ & 3.7 & 0.02 & $1.5-4.3$ & 3.4 & 0.8 \\
\hline LMW/HMW PAHs ratio & $0.18-0.45$ & 0.33 & 0.10 & $0-0.72$ & 0.32 & 0.19 & $0.22-0.63$ & 0.37 & 0.15 \\
\hline Ant $/($ Ant + Phe $)$ ratio & $0.02-0.57$ & 0.15 & 0.16 & $0.02-0.25$ & 0.10 & 0.08 & $0.03-0.35$ & 0.15 & 0.11 \\
\hline $\mathrm{Fla} /($ Fla + Pyr $)$ ratio & $0.10-0.60$ & 0.50 & 0.13 & $0.50-0.58$ & 0.54 & 0.03 & $0.38-0.55$ & 0.48 & 0.05 \\
\hline $\mathrm{BaA} /(\mathrm{BaA}+\mathrm{Chr})$ ratio & $0.12-0.60$ & 0.31 & 0.17 & $0.18-0.31$ & 0.24 & 0.04 & $0.18-0.32$ & 0.27 & 0.04 \\
\hline $\mathrm{InP} /(\operatorname{InP}+\mathrm{BgP})$ ratio & $0.29-0.48$ & 0.42 & 0.05 & $0.30-0.88$ & 0.43 & 0.15 & $0.39-0.48$ & 0.42 & 0.03 \\
\hline
\end{tabular}

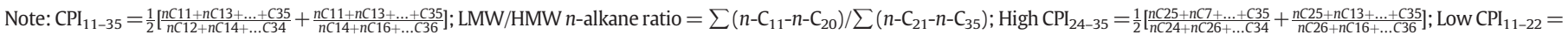

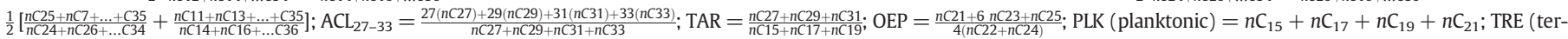

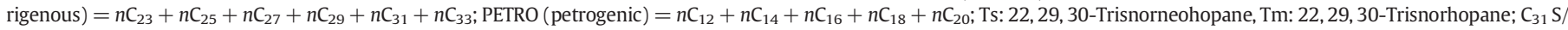

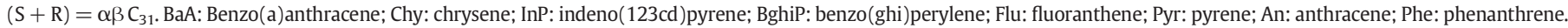
SD denotes standard deviation; LD, limit of detection.

Other than spatial variations, $n$-alkanes showed strong seasonal variations with two major chromatographic patterns (Fig. S1a, b, c). The first pattern displayed a significant odd even carbon number predominance (OEP) at the long-chain range, with $n$-alkane peaked at $n-C_{29}$, indicative of dominant contribution from terrestrial higher plant waxes (Brassell and Eglinton, 1980). The second pattern presented an insignificant $\mathrm{OEP}$ with peak chain length at $\mathrm{C}_{17}-\mathrm{C}_{19}$, indicative of carbon contribution dominated by microbes and phytoplankton (Gogou et al., 2000), nevertheless, the input from petroleum cannot be totally neglected. The latter pattern is similar to that of surface sediments from the Bohai Bay and its adjacent rivers (P. Li et al., 2015; S. Li et al., 2015; Wang et al., 2015). Comparatively, the major chain length ranged from $C_{13}$ to $C_{37}$ with the maximum concentration at $C_{29}\left(C_{\max }=29\right)$ for all the $X(\times 1$ to $\times 11$ ) and Lsp samples with the exception of L1sp, where the $C_{\max }$ was at $C_{17}$. In contrast, the $C_{\max }$ was at $C_{19}$ for all the Lsu samples, except for L2su, L3su, L6su and L7su that had $C_{\max }$ at $C_{18}$ and L9su at $C_{29}$, respectively. It suggested that sources of $n$-alkanes to the Laizhou Bay varied seasonally and may be linked with riverine inputs. Considering that the sedimentation rates of the sampling area in Laizhou Bay varied between 6.4 and $9.4 \mathrm{~cm} / \mathrm{yr}$ ( Li et al., 2012), the seasonal signatures in surface sediments (top ca. $4 \mathrm{~cm}$ ) collected may have been weakened, further implying that the seasonal differences may have been even stronger than the hydrocarbon compositional differences being observed in this study. Similarly, strong seasonal variations in both concentrations and compositions of hydrocarbons have been observed in various river-estuary ecosystems worldwide, such as the Yangtze River estuary, China, and Tamar Estuary, UK and a coastal watershed in Tunisia (Hird and Rowland, 1995; Yu et al., 2016; Gdara et al., 2017).

In order to further decipher spatial and seasonal variations of $n$ alkane sources, multiple deterministic ratios were calculated (Table 1; Fig. 2). The low molecular weight to high molecular weight ratio (LMW/HMW) and terrigenous/aquatic ratio (TAR) have commonly been used as source indicators of $n$-alkanes in estuarine sediments (e.g., Prahl et al., 1994; Hu et al., 2009). LMH/HMW ratios of $>2$ generally indicate fresh oil inputs. LMW/HMW ratios close to 1 represent $n$-alkane from petroleum and phytoplankton, whereas LMH/HMW ratios of $<1$ usually represent terrestrial $n$-alkanes produced by higher plants, marine animals and sedimentary bacteria (Wang et al., 2006). However, with the preferential degradation of LMW hydrocarbons, the presence of heavier oil or more degraded crude oil would result in lower ratios of LMW/HMW (<1) (Commendatore et al., 2000). The LMW/HMW ratios of the $\mathrm{X}$ and Lsp samples were all $<1$, whereas all the Lsu samples (except for station L4su) had LMW/HMW ratios of $>1$. In contrast to the seasonal $n$-alkane differences in this study, previous studies 

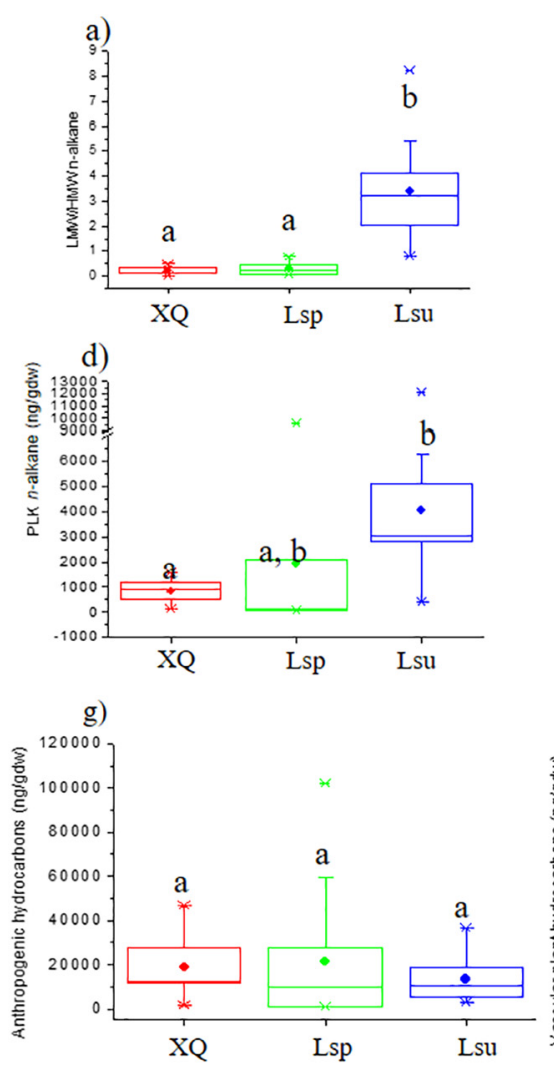
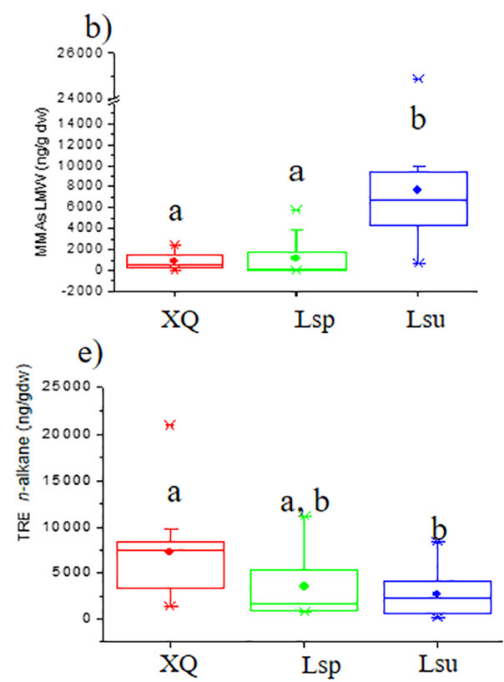

h)

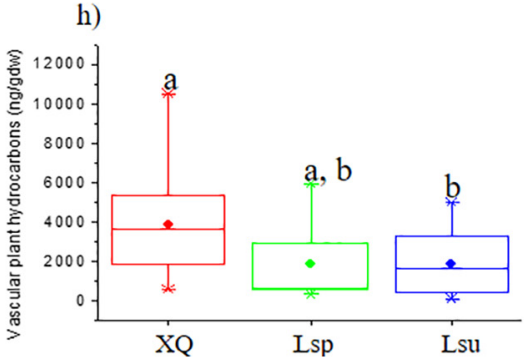

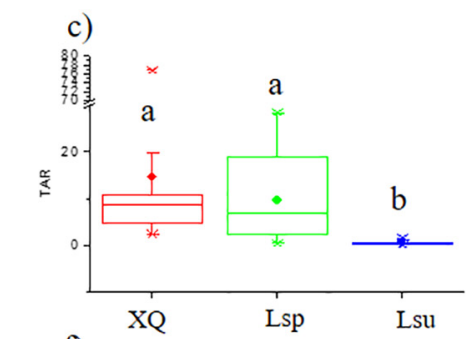
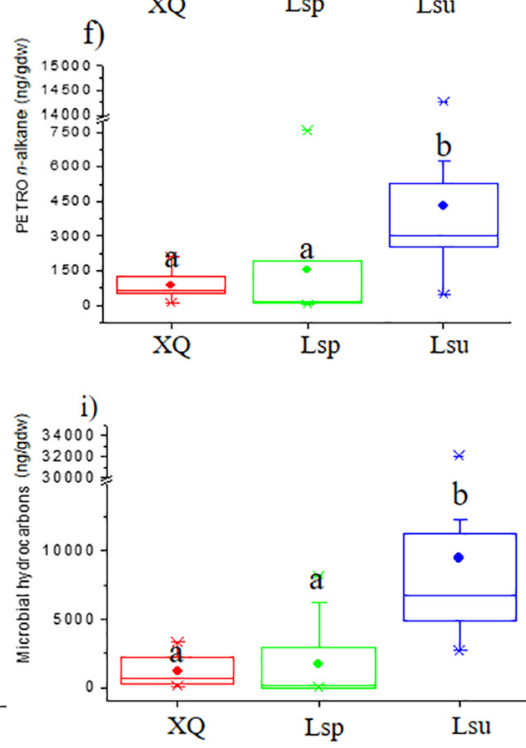

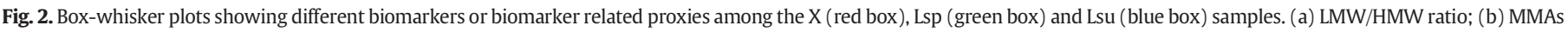

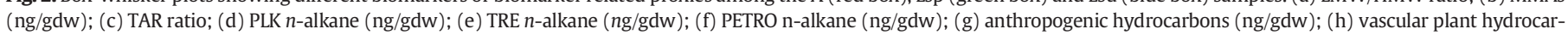
bons (ng/gdw); (i) microbial hydrocarbons (ng/gdw).

observed LMW/HMW of $<1$ in both April and November 2012 in surface sediments from the Bohai Bay and coastal areas off the Yellow River mouth (Wang et al., 2015, 2017). It suggested that the variability of $n$ alkane sources is more frequent than seasonal. The TAR has been widely used to evaluate the relative importance of terrestrial versus aquatic inputs (Silliman et al., 1996; Mille et al., 2007). The TAR values were $>1$ for the $\mathrm{X}$ and Lsp samples, confirming the significance of terrestrial inputs in the Xiaoqing River and coastal area of the Laizhou Bay in spring. High TAR values could also be caused by the preferential preservation of terrestrial hydrocarbons over planktonic ones in coastal environments. However, all the Lsu samples (except for stations L1su and L4su) had TAR values $<1$, suggesting predominant input of $n$-alkanes from aquatic inputs during summer. The seasonal differences in TAR ratios also implied that preferential preservation is unlikely an explanation for high TAR values found in X and Lsp samples. The high $n$ alkane inputs from planktonic source in summer were also supported by the dominance of odd-numbered short chain $n$-alkanes $\left(C_{16}, C_{18}\right.$ and $\mathrm{C}_{20}$ ). In the meantime, planktonic OM may stimulate bacterial community in summer due to warm temperatures (Wu et al., 2001; Alongi et al., 2005; Bianchi, 2011; Resmi et al., 2016), which well explained the predominance of even-numbered short chain $n$-alkanes in some cases. Spatially, TAR ratios did not show any distinct trend, which was likely due to well-mixing of hydrocarbon signatures in this region owing to strong hydrodynamic conditions and gentle sea-floor topography. Similarly, no spatial trend of TAR was also observed from the Yellow River to the Bohai Bay (Wang et al., 2015).

The carbon preference indices (CPI) and average chain length (ACL) are also indicators of OM sources. The $\mathrm{CPI}_{25-35}$, defined by the odd to even HMW $n$-alkanes $\left(C_{25-35}\right)$, has been commonly used to identify vascular plant wax contribution ( $\mathrm{CPI}>1.0$, typically 4.0-6.0) versus fossil fuel contamination (CPI <1.0) (Aboul-Kassim and Simoneit, 1996; Y. He et al., 2014, 2015b, 2016). The high values of $\mathrm{CPI}_{25-35}$ (1.9 to 6.9) together with strong OEP implied that the long chain $n$-alkanes were dominated by vascular plants, consistent with the supposition based on high $\mathrm{ACL}_{27-33}$ values that ranged between 29.0 and 29.9 (avg. 29.6; Table 1). In contrast to $\mathrm{CPI}_{25-35}, \mathrm{CPI}_{11-20}$ values in 25 out of 33 samples (mostly the Lsu samples) were close to 1.0 or $<1.0$ with no obvious OEP, implying inputs from fossil fuel hydrocarbons as well as bacterial activities (Pearson and Eglinton, 2000).

Similar to Ranjbar Jafarabadi et al. (2017, 2018), the sum of phytoplankton- (odd $n$-alkanes from $C_{15}$ to $C_{21}$ ), terrestrial- (odd $n$ alkanes from $C_{23}$ to $C_{33}$ ), and petroleum-derived (even n-alkanes from $\mathrm{C}_{12}$ to $\mathrm{C}_{20}$, PETRO) $n$-alkanes were calculated to estimate their dominance in this study (Table 1 ). The terrestrial derived $n$-alkanes (TRE) were the dominant ( $45 \%$ to $97 \%$ ) in all the $\mathrm{X}$ and Lsp samples, whereas the Lsu samples had more phytoplankton (27\% to $43 \%$ ) and petrogenic sourced $n$-alkanes ( $24 \%$ to $49 \%$ ) (Table 1$)$.

In addition to the diverse $n$-alkanes detected, a wider variety of monomethylated alkanes (MMAs), usually ranging from $C_{12}$ to $C_{24}$, was detected in most sediments. The total concentrations of MMAs ranged from 120 to $3300 \mathrm{ng} / \mathrm{gdw}$, below detection limit to $8200 \mathrm{ng} / \mathrm{gdw}$ and 910 to 32,000 ng/gdw for the X, Lsp and Lsu samples, respectively (Table 1 ). Since MMAs were widely reported in natural and anthropogenic sediments (e.g., oil sand) (D. He et al., 2015a), the short chain MMAs (with carbon chain length $\leq 23$ ) were believed to derive from microbial sources (Han and Calvin, 1969; Shiea et al., 1990), while the long chain MMAs could be derived from diverse sources including microbial and terrigenous inputs (D. He et al., 2015a, 2015b). In this study, the major MMAs featured a carbon chain length from $C_{16}$ to $\mathrm{C}_{20}$ and the methyl substituents at both even- and odd-numbered carbon atoms (Fig. S4), indicative of predominant inputs from microbial sources (Shiea et al., 1990; Kenig et al., 1995). The average concentration of MMAs detected in the Lsu samples was significantly higher $(>6$ to 9 times) than those of the $\mathrm{X}$ and Lsp samples (Fig. 2). Moreover, the 
concentrations of the LMW MMAs were even higher than $n$-alkanes within the range of $C_{11}$ to $C_{20}$ in the Lsu samples. The distinctive differences of MMAs abundances between summer and spring suggested significantly higher microbial inputs during summer, possibly owing to higher temperature and phytoplankton-derived OM (Carstensen et al., 2015).

Unresolved complex mixture (UCM), a mixture of structurally complex isomers of homologous branched and cyclic hydrocarbons that cannot be resolved by capillary columns, is another effective indicator of petroleum contamination, such as chronic emission from vehicles, volatiles from diesel (Simoneit, 1989; Gough and Rowland, 1990; Tolosa et al., 2004; Mille et al., 2007) and degraded petroleum (Brassell and Eglinton, 1980). Nevertheless, bacteria-derived UCMs cannot be ignored (Bouloubassi et al., 2001). In this study, the UCM was evident in most samples. The ratio of UCM $/ n$-alkanes ranged from 0.26 to 0.94 , indicating a pollution diluted by natural inputs for all samples (Silva et al., 2012). The highest concentrations were found in L1 during both spring (25,000 ng/gdw) and summer (130,000 ng/gdw), consistent with overall significant petroleum inputs at this location as mentioned earlier. Generally, UCM in the lower chain-length end $\left(<\mathrm{C}_{20}\right)$ is associated with slightly weathered petroleum since heavy weathering removes LMW and shifts UCM toward HMW (Jacquot et al., 1999; Lima et al., 2012). UCM occurred as both short-chain $(C<20)$ and long chain $(C>25)$ hydrocarbons in all the $X$ and Lsp samples, but occurred predominantly as short-chain hydrocarbons in all the Lsu samples (Fig. S1), suggesting more chronic petroleum contamination in summer. In addition to petroleum derivative inputs, microbial reworking is an additional source of UCM on the short-chain end (Carstensen et al., 2015). However, since UCM derived from microbial reworking is a process over long-time scales (longer than a year), the UCM detected in this study should be driven by petrogenic input.

3.2.2. Spatiotemporal variability of petrogenic biomarkers: hopanes, steranes, gammacerane, $\beta$-carotane, pristine and phytane

Although petrogenic hydrocarbon inputs have been suggested by $n$ alkanes derived indices, the presence of petrogenic hydrocarbons is further confirmed through the identification of a suit of petroleum and fossil carbon related biomarkers, including the hopane and sterane series, pristane (Pr), phytane $(\mathrm{Ph})$, gammacerane and $\beta$-carotane (Philp and Fan, 1987; Fu and Sheng, 1989; Volkman et al., 1992). For example, $\mathrm{Pr} / \mathrm{Ph}$ ratio was $<0.9$ in all samples, suggestive of petrogenic OM inputs. Coincidently, much lower ratios of $\mathrm{Pr} / n-\mathrm{C}_{17}$ and $\mathrm{Ph} / n-\mathrm{C}_{18}$ in the Lsu samples $(<1)$ than in the $\mathrm{X}$ and Lsp samples $(\geq 1)$ were highly linked with a recent oil pollution in summer, 2014 (Mille et al., 2007; Commendatore et al., 2012). Additionally, steranes and hopanes were detected in all samples. The tight correlation $\left(R^{2}=0.99, P<0.0001\right)$ between steranes and hopanes suggested their common sources and similar dynamic processes from the Xiaoqing River to the Laizhou Bay (Fig. S5).

Gammacerane, a nonhopanoid $C_{30}$ triterpane, was detected in all samples except $\times 7$. This compound is commonly found in most Chinese crude oils formed in lacustrine environments (Philp and Fan, 1987). $\beta$ Carotane, derived from carotenoids in photosynthetic plants or microbes, was detected in 30 out of 33 samples, with the highest concentration at L3sp followed by $\times 3$ and L1sp. This compound has been reported in several oil sands in the Bohai Bay Basin (Wang et al., 2013) and is widely used as an indicator of petroleum inputs (Fu and Sheng, 1989; Chen et al., 1996).

The hopane indice, Ts/Tm, ranged from 0.7 to $1.0,0.7$ to 1.0 and 0.7 to 1.2 for the X, Lsp and Lsu samples, respectively, while the ratios of 22S/ $(22 \mathrm{~S}+22 \mathrm{R})$ epimers of $\alpha \beta \mathrm{C}_{31}$ homohopanes had a narrow range of $0.55-0.60$ (Fig. S6), comparable to the equilibrium oil with full maturity (Peters et al., 2005). Similar hopane indices were reported for the surface sediments in the Yellow River Estuary (Wang et al., 2011), possibly owing to similar sources of petrogenic contaminants to those found in Laizhou Bay. The gammacerane $/ C_{30}$ hopane ratios were all $<0.2$, except sample L6su (Fig. S6). These ratios are different to oils from Shengli oil field (e.g., Shi et al., 1982), but similar to those observed in a recent study from the surface sediments in Laizhou Bay (Sun et al., 2018), suggesting the majority of oil pollution may not be directly from Shengli oil field. Furthermore, the ratios of dibenzothiophene to phenanthrene and $\mathrm{Pr} / \mathrm{Ph}$ ratios ranged from 0.05 to 0.17 and 0.38 to 0.90 (Fig. S6), respectively, pointing to a potential oil sourced from a lacustrine (sulfatepoor) depositional environment with variable lithologies (Hughes et al., 1995). Based on these biomarkers and proxies, the petrogenic hydrocarbon inputs in this region were either from oil pollution most likely contributed by occasional oil spills due to intense traffic of ships, or fossil organic carbon from upstream Xiaoqing River with similar biomarker distributions.

\subsubsection{Spatiotemporal variability of linear alkylbenzenes (LABS)}

LABs are raw material for synthesizing anionic surfactants that are commonly used in synthetic detergents. The occurrence of LABs in the aquatic environment is therefore resulted from their incomplete sulfonation during the synthesis of detergents and the subsequent sewage discharge associated with domestic wastes (Raymundo and Preston, 1992). LABs with alkyl chains ranging from 10 to 13 carbon atoms ( $\mathrm{C}_{10}$-LABs, $\mathrm{C}_{11}$-LABs, $\mathrm{C}_{12}$-LABs and $\mathrm{C}_{13}$-LABs; Tables 1 ; $\mathrm{S} 2-\mathrm{S} 4$ ) were detected in all samples and were dominated by $\mathrm{C}_{12}$-LABs, in agreement with the most common composition in commercial detergents (Raymundo and Preston, 1992). The total LABs concentrations varied between 30 and $2700 \mathrm{ng} / \mathrm{gdw}$ and were similar to those reported in estuarine sediments from the North Sea (Raymundo and Preston, 1992) and a largest lagoon in South America (Medeiros et al., 2005), but lower than levels reported in sediments from the Tokyo Bay (Takada and Ishiwatari, 1987). The highest concentration was observed at station L1sp within the Yangkou harbor (2700 ng/gdw), suggesting accumulation of considerable domestic wastes from upstream and local harbor. The second highest concentration of LABs was detected at station $\times 1$ (2300 ng/gdw), which is located in Jinan City, the largest city in Shandong province with a population of ca. 7.1 million (Fig. 1). Station $\times 1$ was thus susceptible to severe sewage discharges from both domestic and industrial sewage inputs (He et al., 2018).

\subsubsection{Spatiotemporal variability of $\mathrm{PAHS}$}

The concentrations of PAHs were 970 to 32,000, 70 to 51,000 and 100 to $10,000 \mathrm{ng} / \mathrm{gdw}$ for the X, Lsp and Lsu samples, respectively (Table 1), without significant differences among each group. These ranges were larger than most typical estuaries in China, such as the Yellow River Delta (3590 to 27,100 ng/gdw; Wang et al., 2011), Yangtze River Estuary ( 27 to 622 ng/gdw; Wang et al., 2016), and Pearl River Estuary (126 to $3829 \mathrm{ng} / \mathrm{gdw}$; Zhang et al., 2015), suggesting generally higher anthropogenic inputs in Xiaoqing River and Laizhou Bay system. Based on the pollution levels defined by Baumard et al. (1998), most of the stations were characterized by moderate to extensively high pollution levels, with the most severe cases at stations $\times 1$ and L1sp.

In order to identify potential sources of PAHs, four commonly used diagnostic ratios were proposed (Fig. S7; Table 1), including anthracene to anthracene plus phenantrene [Ant/(Phy + Ant)] ratio, fluoranthene to fluoranthene plus pyrene $[\mathrm{Flu} /(\mathrm{Flu}+\mathrm{Pyr})]$ ratio, indeno(123cd) pyrene to indeno(123cd)pyrene plus benzo[ghi]perylene [ InP/(InP + BghiP)] ratio, and benzo(a)anthracene to benzo(a)anthracene plus chrysene $[\mathrm{BaA} /(\mathrm{BaA}+\mathrm{Chry})]$ ratio (Yunker et al., 2002). In this study, the wide range of $[$ Ant/(Phe + Ant)] ratios (0.02-0.57) and most of the $[\mathrm{BaA} /(\mathrm{BaA}+\mathrm{Chry})]$ ratios suggested mixing sources. The high ratios of $[\mathrm{Flu} /(\mathrm{Flu}+\mathrm{Pyr})](>0.4)$ at most stations constrained the PAHs being dominated by combustion sources. Furthermore, the $[\operatorname{InP} /(\operatorname{InP}$ + BghiP)] ratios implied the most possible mechanism was fossil fuel combustion. However, it is noteworthy that these diagnostic ratios sometimes come with multiple explanations, especially in estuarine environments (Yunker et al., 2002). Examples of inconsistencies based on $\mathrm{PAH}$ diagnostic ratios have been reported in Persian Gulf, Iran (e.g., Ranjbar Jafarabadi et al., 2017). Therefore, our study area serves 
as another system that these PAH diagnostic ratios may not work perfectly in tracking sources of PAHs. Furthermore, neither concentrations nor compositions of PAHs showed strong seasonal differences, which is in contrast with the sharp seasonal differences of aliphatic hydrocarbons (Figs. S1, S2; Fig. 2). It further suggested that sources of PAHs may differ to those of aliphatic hydrocarbons, and implied that data interpretation in coastal systems like this could be strongly biased if only one group of biomarkers was used.

3.3. Spatiotemporal variability revealed by overall hydrocarbon distribution patterns and statistical analyses

Although multiple biomarkers have been applied in carbon source-tracking in previous sections, we further used these biomarkers for a semi-quantitative estimation of hydrocarbon sources, e.g., anthropogenic, microbial, and vascular plant sources. In this study, the sum of petroleum $n$-alkanes, hopanes, steranes, LABs, $\beta$ carotane, gammacerane and PAHs was used to assess anthropogenic sources of hydrocarbons. The total concentrations of MMAs and leaf wax $n$-alkanes were used to assess microbial and vascular plant sources, respectively. The relative percentage of each source was roughly calculated by taking the sum of the hydrocarbon biomarker of that source divided by the sum of all hydrocarbon biomarkers detected (anthropogenic, microbial and vascular plant biomarkers) and multiplied by 100 . Currently, we admit that it is impossible to precisely assess the relative percentage of each source of hydrocarbons to a particular sample because (i) the contribution degree of each types of hydrocarbons may vary depending on their significance in each source; and (ii) the limitation of GC-MS which can only detect part of hydrocarbons, increasing the variability of calculations. Although this calculation must introduce lots of uncertainties, it is helpful to assess the variability among different samples, and thus has been applied in numerous studies (Pisani et al., 2013; Rushdi et al., 2014, 2017, 2018). Therefore, based on our criteria specified above, the anthropogenic derived hydrocarbons detected were 940 to $100,000 \mathrm{ng} / \mathrm{gdw}$. The vascular plant derived hydrocarbons detected were from 100 to $11,000 \mathrm{ng} / \mathrm{gdw}$, whereas the microbial derived hydrocarbons detected were from $<$ LD (limit of detection) to $32,000 \mathrm{ng} / \mathrm{gdw}$ (Fig. 2). Anthropogenic derived hydrocarbons were the dominant in most stations (38\% to 97\%), suggesting anthropogenic influences were the major driver of hydrocarbon inputs in Xiaoqing River and Laizhou Bay, a typical eutrophication area in eastern China. The averaged relative percentages of terrestrial and anthropogenic hydrocarbons were significantly higher $(P<0.01)$ in the Lsp samples than Lsp samples, whereas microbial derived hydrocarbons were significantly higher $(P<0.01)$ in the Lsu samples (18\% to $58 \%$ ) than Lsp samples (0 to 10\%; Fig. 2; Table S5).

PCA was further used to distinguish groups of samples based on stations and to assess sources, spatial and seasonal variations of hydrocarbons (Fig. 3). The first PCA included all saturated hydrocarbons, including $n$-alkanes, MMAs, hopanes, steranes, LABs, $\beta$-carotane, UCM, and some commonly used ratios, such as CPI, ACL, TAR (Table 1; Fig. 2), as variables. In this analysis, the first and second principal components (PC) explained $39.0 \%$ and $24.7 \%$ of the total variation, respectively. Based on PCA loadings, samples were distinguished into two groups according to their origins: (i) the Lsu samples dominated by MMAs, $\mathrm{ACL}_{27-33}, \mathrm{CPI}_{24-36}$, and PLK, and (ii) the Lsp and $\mathrm{X}$ samples by petrogenic biomarkers (hopanes, steranes, $\beta$-carotane), LABs, HMW $n$ alkanes, TRE, TAR, and petrogenic $n$-alkanes (PETRO). Without any significant differences, these two groups of samples were only separated along the PC2. Based on the loading of each parameter, the Lsu samples were characterized by more phytoplankton and microbial inputs compared with the $\mathrm{X}$ and Lsp samples, which were more enriched in petrogenic hydrocarbons and anthropogenic derived biomarkers, such as LABs. All in all, our data demonstrated that the saturated hydrocarbons had strong seasonal differences, while spatial differences were not observed based on PCA.
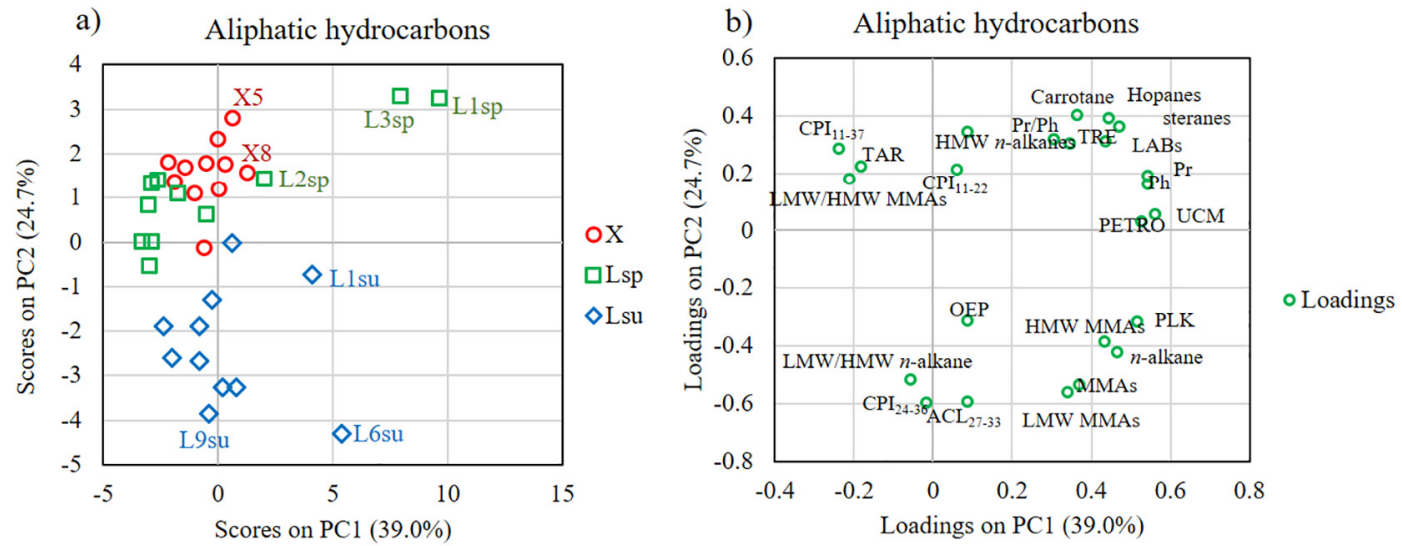

c) PAHs
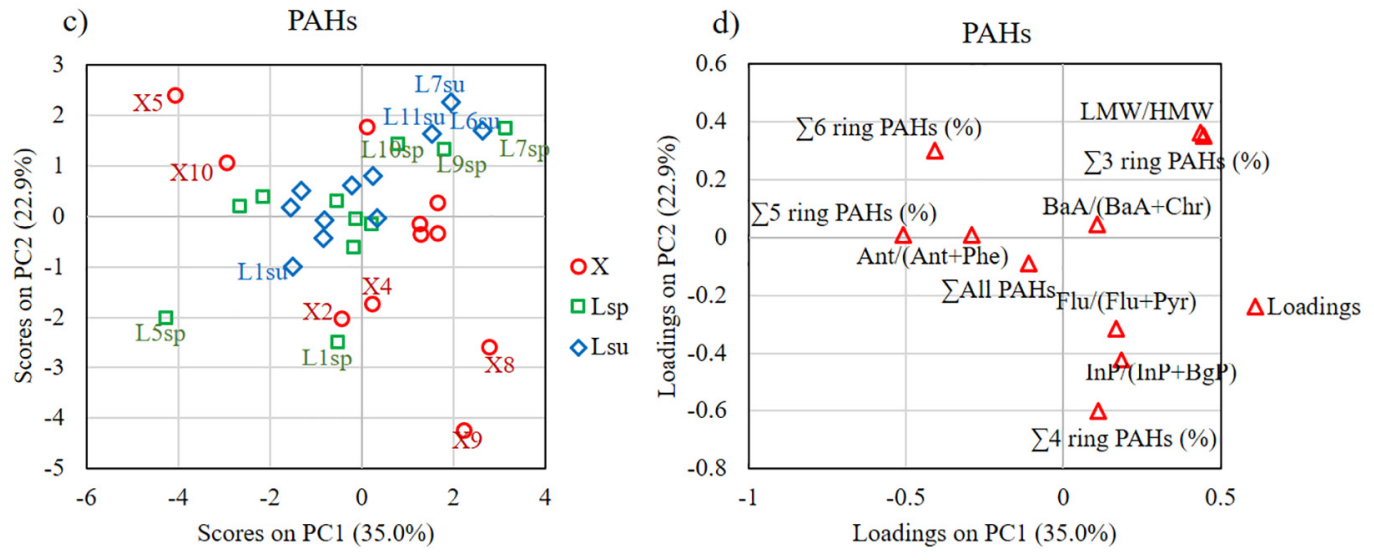

Fig. 3. Principal component analysis using aliphatic hydrocarbons as loadings (a, b) and various PAHs as loadings (c, d). 
As mentioned earlier, seasonal differences seemed not to be observed for PAHs, therefore, the second PCA analysis was specifically on PAHs to further investigate the driving force of their variation (Fig. 3). The PC1, explaining $35.0 \%$ of the total variation, was positively associated with LMW PAHs (e.g., 3-ring PAHs), and negatively correlated with HMW PAHs, especially 5-ring PAHs. The PC2, explaining $22.9 \%$ of the variability, was associated inversely with 4 -ring PAHs. The PCA loadings distinguished three groups of samples according to their origins: (i) a group mainly composed of LWM PAHs (3 rings), (ii) a group dominated by HMW PAHs ( 5 and 6 rings), and (iii) a group primarily constructed by middle molecular weight PAHs (4 rings). The X, Lsp and Lsu samples were not distinguished spatially or seasonally based on PCA scores, suggesting overall non-point source inputs of PAHs across our study area. Nevertheless, stations away from the Xiaoqing River mouth, such as L7-L11, seemed to be more associated with LMW PAHs and therefore higher LMW/HMW PAHs ratios. Since LMW PAHs are more volatile, they have higher chances of being transported over longer distances than HMW PAHs. Therefore, atmospheric deposition may be one of the most important processes affecting the distribution of PAHs. However, further spatial and seasonal investigations of the aerosol PAHs in this area are needed in the future in order to confirm this speculation.

\section{Conclusion}

The study demonstrated the necessity of applying multiple biomarkers in comprehensively characterizing hydrocarbon inputs at seasonal or even monthly levels. Our results demonstrated that each group of biomarkers have its advantages in tracking specific sources of carbon inputs. Our study also confirmed that the characterization of hydrocarbons to riverine-coastal systems may vary more frequently than seasonal. By using multiple biomarkers, anthropogenic sourced hydrocarbons were found to be the dominant ones in this area. This is consistent with our expectation since this region is influenced severely by anthropogenic activities.

The dominant anthropogenic hydrocarbons detected were derived mainly from petroleum and manufacturing activities. In particular, the ubiquitous presence of UCM and $\beta$-carotane, gammacerane, and composition patterns of hopanes and steranes, indicated that the petroleum contamination in the Xiaoqing River to Laizhou Bay was mainly from offshore oilfields and ship activities. The presence of LABs suggested strong sewage discharges from surrounding rivers. PAHs concentrations suggested most stations were under moderate to very high pollution levels. Furthermore, PAHs isomeric ratios indicated that the PAHs were mostly of petroleum combustion origin. Besides the anthropogenic input, the natural hydrocarbons were mainly derived from vascular plants, which is indicated by spatial distributions of LMW/HMW, CPI and TAR. Notably, both microbial and phytoplankton inputs were significantly higher in summer than spring, which may be caused by higher temperature, the growth of phytoplankton and associated heterotrophic microbes in summer. PCA revealed that the seasonal differences were higher than the spatial differences for aliphatic hydrocarbons. In contrast, spatial variation was seen in the composition of aromatic hydrocarbons, implying a livelihood of nonpoint source inputs through aerosol. The strong decoupling between aliphatic and aromatic hydrocarbons is important to note for an integrated view of hydrocarbon sources and transportation mechanisms in this ecosystem. Lastly, the current study provided background information for policy making aiming at reducing anthropogenic impacts and promoting the health of this estuarine ecosystem and other typical urbanized river-estuary systems in eastern China.

\section{Acknowledgements}

D. He designed this study. The manuscript was written by D. He and X. Cui. All other authors joined in the data interpretation and discussion.
We also acknowledge Prof. S.Z. Zhang and two anonymous reviewers for their constructive comments, which improves the quality of this work. This work was supported by National Science Foundation of China [41773098 to D. He; 41372131 to Y. Sun], the Chinese Academy of Sciences (KZZD-398 EW-14) and the "100" talent program of Zhejiang University [188020*194231701/008 and 188020-193810201/ 102 to D. He]. This is eBig contribution number 2.

\section{Appendix A. Supplementary data}

Supplementary data to this article can be found online at https://doi. org/10.1016/j.scitotenv.2018.07.193.

\section{References}

Aboul-Kassim, T.A., Simoneit, B.R., 1996. Lipid geochemistry of surficial sediments from the coastal environment of Egypt I. Aliphatic hydrocarbons-characterization and sources. Mar. Chem. 54 (1-2), 135-158.

Alongi, D., Pfitzner, J., Trott, L., Tirendi, F., Dixon, P., Klumpp, D., 2005. Rapid sediment accumulation and microbial mineralization in forests of the mangrove Kandelia candel in the Jiulongjiang Estuary, China. Estuar. Coast. Shelf Sci. 63, 605-618.

Bajt, O., 2012. Aliphatic and polycyclic aromatic hydrocarbons in sediments of the Slovenian coastal area (Gulf of Trieste, northern Adriatic). Environ. Monit. Assess. 184 (12), 7439-7452.

Baumard, P., Budzinski, H., Michon, Q., Garrigues, P., Burgeot, T., Bellocq, J., 1998. Origin and bioavailability of PAHs in the Mediterranean Sea from mussel and sediment records. Estuar. Coast. Shelf Sci. 47, 77-90.

Bouloubassi, I., Fillaux, J., Saliot, A., 2001. Hydrocarbons in surface sediments from the Changjiang (Yangtze river) estuary, East China Sea. Mar. Pollut. Bull. 42 (12), 1335-1346.

Bianchi, T.S., 2011. The role of terrestrially derived organic carbon in the coastal ocean: a changing paradigm and the priming effect. Proc. Natl. Acad. Sci. U.S.A. 108 (49), 19473-19481.

Bianchi, T.S., Canuel, E.A., 2011. Chemical Biomarkers in Aquatic Ecosystems. Princeton University Press.

Birgel, D., Stein, R., Hefter, J., 2004. Aliphatic lipids in recent sediments of the Fram Strait/ Yermak Plateau (Arctic Ocean): composition, sources and transport processes. Mar. Chem. 88 (3), 127-160.

Brassell, S., Eglinton, G., 1980. Environmental chemistry-an inter-disciplinary subject. Natural and pollutant organic compounds in contemporary aquatic environments. Analytical Techniques in Environmental Chemistry: Proceedings of the International Congress, Barcelona, Spain, November 1978. Pergamon, p. 1.

Canuel, E.A., Hardison, A.K., 2016. Sources, ages, and alteration of organic matter in estuaries. Annu. Rev. Mar. Sci. 8, 409-434.

Carstensen, J., Klais, R., Cloern, J.E., 2015. Phytoplankton blooms in estuarine and coastal waters: seasonal patterns and key species. Estuar. Coast. Shelf Sci. 162, 98-109.

Chen, J., Bi, Y., Zhang, J., Li, S., 1996. Oil-source correlation in the Fulin basin, Shengli petroleum province, East China. Org. Geochem. 24, 931-940.

Commendatore, M.G., Esteves, J.L., Colombo, J.C., 2000. Hydrocarbons in coastal sediments of Patagonia, Argentina: levels and probable sources. Mar. Pollut. Bull. 40, 989-998.

Commendatore, M.G., Nievas, M.L., Amin, O., Esteves, J.L., 2012. Sources and distribution of aliphatic and polyaromatic hydrocarbons in coastal sediments from the Ushuaia Bay (Tierra del Fuego, Patagonia, Argentina). Mar. Environ. Res. 74, 20-31.

D'Anjou, R.M., Bradley, R.S., Balascio, N.L., Finkelstein, D.B., 2012. Climate impacts on human settlement and agricultural activities in northern Norway revealed through sediment biogeochemistry. Proc. Natl. Acad. Sci. U.S.A. 109, 20332-20337.

Dong, J., Xia, X., Wang, M., Xie, H., Wen, J., Bao, Y., 2016. Effect of recurrent sediment resuspension-deposition events on bioavailability of polycyclic aromatic hydrocarbons in aquatic environments. J. Hydrol. 540, 934-946.

Eglinton, G., Hamilton, R.J., 1967. Leaf epicuticular waxes. Science 156, 1322-1325.

Fu, J., Sheng, G.Y., 1989. Biological marker composition of typical source rocks and related crude oils of terrestrial origin in the People's Republic of China: a review. Appl. Geochem. 4 (1), 13-22.

Gdara, I., Zrafi, I., Balducci, C., Cecinato, A., Ghrabi, A., 2017. Seasonal distribution, source identification, and toxicological risk assessment of polycyclic aromatic hydrocarbons (PAHs) in sediments from Wadi El Bey Watershed in Tunisia. Arch. Environ. Contam. Toxicol. 73 (3), 488-510.

Gobas, F.A., MacLean, L.G., 2003. Sediment-water distribution of organic contaminants in aquatic ecosystems: the role of organic carbon mineralization. Environ. Sci. Technol. 37 (4), 735-741.

Gogou, A., Bouloubassi, I., Stephanou, E.G., 2000. Marine organic geochemistry of the Eastern Mediterranean: 1 . Aliphatic and polyaromatic hydrocarbons in Cretan Sea surficial sediments. Mar. Chem. 68 (4), 265-282.

Gough, M., Rowland, S., 1990. Characterization of unresolved complex mixtures of hydrocarbons in petroleum. Nature 344, 648-650.

Han, J., Calvin, M., 1969. Hydrocarbon distribution of algae and bacteria, and microbiological activity in sediments. Proc. Natl. Acad. Sci. U.S.A. 64 (2), 436-443.

Harris, K.A., Yunker, M.B., Dangerfield, N., Ross, P.S., 2011. Sediment-associated aliphatic and aromatic hydrocarbons in coastal British Columbia, Canada: concentrations, composition, and associated risks to protected sea otters. Environ. Pollut. 159 (10) 2665. 
He, Y., Zhao, C., Wang, Z., Wang, H., Song, M., Liu, W., Liu, Z.H., 2013. Late Holocene coupled moisture and temperature changes on the northern Tibetan Plateau. Quat. Sci. Rev. 80, 47-57.

He, D., Mead, R.N., Belicka, L., Pisani, O., Jaffé, R., 2014. Assessing source contributions to particulate organic matter in a subtropical estuary: a biomarker approach. Org. Geochem. 75, 129-139.

He, Y., Zheng, Z., Zhao, C., Sun, Y., Pan, A., Zheng, Y., Song, M., Liu, Z., 2014. Biomarker reconstructions of Holocene lake level changes at Lake Gahai on the northeastern Tibetan Plateau. The Holocene 24, 405-412.

He, D., Simoneit, B.R.T., Jara, B., Jaffé, R., 2015a. Compositions and isotopic differences of iso-and anteiso-alkanes in black mangroves (Avicennia germinans) across a salinity gradient in a subtropical estuary. Environ. Chem. 13 (4), 623-630.

He, D., Simoneit, B.R.T., Jara, B., Jaffé, R., 2015b. Occurrence and distribution of monomethylalkanes in the freshwater wetland ecosystem of the Florida Everglades. Chemosphere 119, 258-266.

He, Y., Zhao, C., Song, M., Liu, W., Chen, F., Zhang, D., Liu, Z., 2015a. Onset of frequent dust storms in northern China at $\sim$ AD 1100. Sci. Rep. https://doi.org/10.1038/srep17111.

He, Y., Zhao, C., Zheng, Z., Liu, Z., Wang, N., Li, J., Cheddadi, R., 2015b. Peatland evolution and associated environmental changes in central China over the past 40,000 years. Quarternary Res. 84, 255-261.

He, Y., Sun, D., Wu, J., Sun, Y., 2015c. Factors controlling the past 150 -year ecological dynamics of lake Wuliangsu in the upper reaches of the Yellow River, China. The Holocene 187, 1394-1401.

He, D., Anderson, W.T., Jaffé, R., 2016a. Compound specific $\delta \mathrm{D}$ and $\delta^{13} \mathrm{C}$ analyses as a tool for the assessment of hydrological change in a subtropical wetland. Aqua. Sci. 78, 809-822.

He, D., Simoneit, B.R., Xu, Y., Jaffé, R., 2016b. Occurrence of unsaturated C 25 highly branched isoprenoids (HBIs) in a freshwater wetland. Org. Geochem. 93, 59-67.

He, Y., Zhao, C., Liu, Z., Wang, H., Liu, W., Yu, Z., Zhao, Y., 2016. Holocene climate controls on water isotopic variations on the northeastern Tibetan Plateau. Chem. Geol. 440, 239-247.

He, D., Zhang, K., Tang, J., Cui, X., Sun, Y., 2018. Using fecal sterols to assess dynamics of sewage input in sediments along a human-impacted river-estuary system in eastern China. Sci. Total Environ. 636, 787-797.

Hird, S.J., Rowland, S.J., 1995. An investigation of the sources and seasonal variations of highly branched isoprenoid hydrocarbons in intertidal sediments of the Tamar Estuary, UK. Mar. Environ. Res. 40 (4), 423-437.

Hu, L.M., Guo, Z.G., Feng, J.L., Yang, Z.S., Fang, M., 2009. Distributions and sources of bulk organic matter and aliphatic hydrocarbons in surface sediments of the Bohai Sea China. Mar. Chem. 113, 197-211.

Hu, N.J., Shi, X.F., Huang, P., Liu, J.H., 2011. Polycyclic aromatic hydrocarbons in surface sediments of Laizhou Bay, Bohai Sea, China. Environ. Earth Sci. 63 (1), 121-133.

Hughes, W.B., Holba, A.G., Dzou, L.I., 1995. The ratios of dibenzothiophene to phenanthrene and pristane to phytane as indicators of depositional environment and lithology of petroleum source rocks. Geochim. Cosmochim. Acta 59 (17), 3581-3598.

Jacquot, F., Le Dreau, Y., Doumenq, P., Munoz, D., Guiliano, M., Imbert, G., Mille, G., 1999 The origins of hydrocarbons trapped in the lake of Berre sediments. Chemosphere 39. $1407-1419$

Jiang, T., Skyllberg, U., Bjorn, E., Green, N.W., Tang, J., Wang, D., Gao, J., Li, C., 2017. Characteristics of dissolved organic matter (DOM) and relationship with dissolved mercury in Xiaoqing River-Laizhou Bay estuary, Bohai Sea, China. Environ. Pollut. 223 $19-30$.

Kenig, F., Damsté, J.S.S., Kock-van Dalen, A.C., Rijpstra, W.I.C., Huc, A.Y., de Leeuw, J.W., 1995. Occurrence and origin of mono-, di-, and trimethylalkanes in modern and Hoocene cyanobacterial mats from Abu Dhabi, United Arab Emirates. Geochim. Cosmochim. Acta 59 (14), 2999-3015

Kostka, J.E., Prakash, O., Overholt, W.A., Green, S.J., Freyer, G., Canion, A., Delgardio, J. Norton, N., Hazen, T.C., Huettel, M., 2011. Hydrocarbon-degrading bacteria and the bacterial community response in Gulf of Mexico beach sands impacted by the Deepwater Horizon oil spill. Appl. Environ. Microbiol. 77, 7962-7974.

Li, J., Hu, B.Q., Dou, Y.G., Zhao, J.T., Li, G.G., 2012. Modern sedimentation rate, budget and supply of the muddy deposits in the East China Seas. Geol. Rev. (in Chinese) 58 (4) 745-756.

Li, P., Cao, J., Diao, X., Wang, B., Zhou, H., Han, Q., Zheng, P., Li, Y., 2015a. Spatial distribution, sources and ecological risk assessment of polycyclic aromatic hydrocarbons in surface seawater from Yangpu Bay, China. Mar. Pollut. Bull. 93, 53-60.

Li, S., Zhang, S., Dong, H., Zhao, Q., Cao, C., 2015b. Presence of aliphatic and polycyclic aromatic hydrocarbons in near-surface sediments of an oil spill area in Bohai Sea. Mar. Pollut. Bull. 100 (1), 169-175.

Lima, M.B., Feitosa, E.A., Emídio, E.S., Dorea, H.S., Alexandre, M.R., 2012. Distribution and sources of aliphatic hydrocarbons in surface sediments of Sergipe River estuarine system. Mar. Pollut. Bull. 64, 1721-1725.

Liu, W., Ning, Y., An, Z., Wu, Z., Lu, H., Cao, Y., 2005. Carbon isotopic composition of modern soil and paleosol as a response to vegetation change on the Chinese loess plateau. Sci. China 48, 93-99.

Liu, A., Lang, Y., Xue, L., Liu, J., 2009. Ecological risk analysis of polycyclic aromatic hydrocarbons (PAHs) in surface sediments from Laizhou Bay. Environ. Monit. Assess. 159 (1), 429-436.

Liu, L.Y., Wang J.Z., Wei, G.L., Guan, Y.F., Zeng, E.Y., 2012. Polycyclic aromatic hydrocarbons (PAHs) in continental shelf sediment of China: implications for anthropogenic influences on coastal marine environment. Environ. Pollut. 167, 155-162.

McCallister, S.L., Bauer, J.E., Cherrier, J.E., Ducklow, H.W., 2004. Assessing sources and ages of organic matter supporting river and estuarine bacterial production: a multipleisotope $\left(\Delta^{14} C, \delta^{13} C\right.$, and $\left.\delta^{15} \mathrm{~N}\right)$ approach. Limnol. Oceanogr. 49, 1687-1702.

Medeiros, P.M., Bícego, M.C., Castelao, R.M., Del Rosso, C., Fillmann, G., Zamboni, A.J., 2005 Natural and anthropogenic hydrocarbon inputs to sediments of Patos Lagoon Estuary, Brazil. Environ. Int. 31 (1), 77-87.
Meyers, P.A., 1997. Organic geochemical proxies of paleoceanographic, paleolimnologic, and paleoclimatic processes. Org. Geochem. 27 (5-6), 213-250.

Mille, G., Asia, L., Guiliano, M., Malleret, L., Doumenq, P., 2007. Hydrocarbons in coastal sediments from the Mediterranean Sea (Gulf of Fos area, France). Mar. Pollut. Bull. 54, 566-575

Pan, X., Tang, J., Li, J., Zhong, G., Chen, Y., Zhang, G., 2011. Polybrominated diphenyl ethers (PBDEs) in the riverine and marine sediments of the Laizhou Bay area, north China. J. Environ. Monit. 13 (4), 886.

Pang, X., Li, M., Li, S., Jin, Z., 2003. Geochemistry of petroleum systems in the Niuzhuang South Slope of Bohai Bay Basin. Part 2: evidence for significant contribution of mature source rocks to "immature oils" in the Bamianhe field. Org. Geochem. 34 (7), 931-950.

Pearson, A., Eglinton, T.I., 2000. The origin of $n$-alkanes in Santa Monica Basin surface sediment: a model based on compound-specific $\delta^{14} \mathrm{C}$ and $\delta{ }^{13} \mathrm{C}$ data. Org. Geochem. 31, $1103-1116$.

Peters, K.E., Walters, C.C., Moldowan, J.M., 2005. The Biomarker Guide, Biomarkers and Isotopes in Petroleum Exploration and Earth History. second ed. vol. 2. Cambridge University Press, UK.

Philp, R.P., Fan, Z., 1987. Geochemical investigation of oils and source rocks from Qianjiang depression of Jianghan basin, a terrigenous saline basin, China. Org. Geochem. 11 (6), 549-562.

Pisani, O., Oros, D.R., Oyo-Ita, O.E., Ekpo, B.O., Jaffé, R., Simoneit, B.R.T., 2013. Biomarkers in surface sediments from the cross river and estuary system, SE Nigeria: assessment of organic matter sources of natural and anthropogenic origins. Appl. Geochem. 31 (2), 239-250.

Prahl, F.G., Ertel, J.R., Goni, M.A., Sparrow, M.A., Eversmeyer, B., 1994. Terrestrial organic carbon contributions to sediments on the Washington margin. Geochim. Cosmochim. Acta 58, 3035-3048.

Ranjbar Jafarabadi, A., Bakhtiari, A.R., Aliabadian, M., Toosi, A.S., 2017. Spatial distribution and composition of aliphatic hydrocarbons, polycyclic aromatic hydrocarbons and hopanes in superficial sediments of the coral reefs of the Persian Gulf, Iran. Environ. Pollut. 224, 195-223.

Ranjbar Jafarabadi, A., Riyahi Bakhtiari, A., Aliabadian, M., Laetitia, H., Kong Yap, C., 2018. First report of bioaccumulation and bioconcentration of aliphatic hydrocarbons (AHs) and persistent organic pollutants (PAHs, PCBs and PCNs) and their effects on alcyonacea and scleractinian corals and their endosymbiotic algae from the Persian Gulf, Iran: inter and intra-species differences. Sci. Total Environ. 627 (15), 141-157.

Raymundo, C.C., Preston, M.R., 1992. The distribution of linear alkylbenzenes in coastal and estuarine sediments of the Western North Sea. Mar. Pollut. Bull. 24 (3), 138-146.

Resmi, P., Manju, M., Gireeshkumar, T., Kumar, C.R., Chandramohanakumar, N., 2016. Source characterisation of sedimentary organic matter in mangrove ecosystems of northern Kerala, India: inferences from bulk characterisation and hydrocarbon biomarkers. Reg. Stud. Mar. Sci. 7, 43-54.

Rushdi, A.I., DouAbul, A.A., Mohammed, S.S., Simoneit, B.R.T., 2006. Compositions and sources of extractable organic matter in Mesopotamian marshland surface sediments of Iraq. I: aliphatic lipids. Environ. Geol. 50 (6), 857-866.

Rushdi, A.I., Simoneit, B.R., DouAbul, A.A., Al-Mutlaq, K.F., El-Mubarak, A.H., Qurban, M., Goni, M.A., 2014. Occurrence and sources of polar lipid tracers in sediments from the Shatt al-Arab River of Iraq and the northwestern Arabian Gulf. Sci. Total Environ. 470, 180-192.

Rushdi, A.I., Al-Shaikh, I., El-Mubarak, A.H., Alnaimi, H.A., Al-Shamary, N., Hassan, H.M., Assali, M.A., 2017. Characteristics and sources of anthropogenic and biogenic hydrocarbons in sediments from the coast of Qatar. Mar. Pollut. Bull. 124 (1), 56-66.

Rushdi, A.I., Douabul, A.A.Z., Al-Maarofi, S.S., Simoneit, B.R.T., 2018. Impacts of mesopotamian wetland re-flooding on the lipid biomarker distributions in sediments. J. Hydrol. 558.

Shi, J.Y., Mackenzie, A.S., Alexander, R., Eglinton, G., Gowar, A.P. Wolff, G.A., Maxwell, J., 1982. A biological marker investigation of petroleums and shales from the Shengli Oilfield, the People's Republic of China. Chem. Geol. 35 (1-2), 1-31.

Shiea, J., Brassell, S.C., Ward, D.M., 1990. Mid-chain branched mono-and dimethyl alkanes in hot spring cyanobacterial mats: a direct biogenic source for branched alkanes in ancient sediments? Org. Geochem. 15 (3), 223-231.

Shirneshan, G., Bakhtiari, A.R., Memariani, M., 2016. Distribution and origins of $n$-alkanes, hopanes, and steranes in rivers and marine sediments from Southwest Caspian coast, Iran: implications for identifying petroleum hydrocarbon inputs. Environ. Sci. Pollut. Res. 23, 1-12

Silliman, J.E., Meyers, P.A., Bourbonniere, R.A., 1996. Record of postglacial organic matter delivery and burial in sediments of Lake Ontario. Org. Geochem. 24 (4), 463-472.

Silva, T.R., Lopes, S.R., Sporl, G., Knoppers, B.A., Azevedo, D.A., 2012. Source characterization using molecular distribution and stable carbon isotopic composition of nalkanes in sediment cores from the tropical Mundaúe Manguaba estuarine-lagoon system. Braz. Org. Geochem. 53, 25-33.

Simoneit, B.R.T., 1989. Organic matter of the troposphered V: application of molecular marker analysis to biogenic emissions into the troposphere for source reconciliations. J. Atmos. Chem. 8, 251-275.

Sun, D., Tang, J., He, Y., Liao, W., Sun, Y., 2018. Sources, distributions, and burial efficiency of terrigenous organic matter in surface sediments from the Yellow River mouth, northeast China. Org. Geochem. 118, 89-102.

Takada, H., Ishiwatari, R., 1987. Linear alkylbenzenes in urban riverine environments in Tokyo: distribution, source, and behavior. Environ. Sci. Technol. 21 (9(9)), 875-883.

Tao, S., Eglinton, T.I., Montluçon, D.B., McIntyre, C., Zhao, M., 2015. Pre-aged soil organic carbon as a major component of the Yellow River suspended load: regional significance and global relevance. Earth Planet. Sci. Lett. 414, 77-86.

Tolosa, I., De, M.S., Sheikholeslami, M.R., Villeneuve, J.P., Bartocci, J., Cattini, C., 2004. Aliphatic and aromatic hydrocarbons in coastal Caspian Sea sediments. Mar. Pollut. Bull. 48, 44-60. 
Volkman, J.K., Holdsworth, D.G., Neill, G.P., Bavor Jr., H.J., 1992. Identification of natural, anthropogenic and petroleum hydrocarbons in aquatic sediments. Sci. Total Environ. $112,203-219$.

Wakeham, S.G., 1996. Aliphatic and polycyclic aromatic hydrocarbons in Black Sea sediments. Mar. Chem. 53, 187-205.

Wang, X.C., Sun, S., Ma, H.Q., Liu, Y., 2006. Sources and distribution of aliphatic and polyaromatic hydrocarbons in sediments of Jiaozhou Bay, Qingdao, China. Mar. Pollut. Bull. 52 (2), 129-138.

Wang, C., Wang, W., He, S., Du, J., Sun, Z., 2011. Sources and distribution of aliphatic and polycyclic aromatic hydrocarbons in Yellow River Delta Nature Reserve, China. Appl. Geochem. 26, 1330-1336.

Wang, G., Wang, T.G., Simoneit, B.R.T., Zhang, L., 2013. Investigation of hydrocarbon biodegradation from a downhole profile in Bohai Bay Basin: implications for the origin of 25-norhopanes. Org. Geochem. 55, 72-84.

Wang, M., Wang, C., Hu, X., Zhang, H., He, S., Lv, S., 2015. Distributions and sources of petroleum, aliphatic hydrocarbons and polycyclic aromatic hydrocarbons (PAHs) in surface sediments from Bohai bay and its adjacent river, China. Mar. Pollut. Bull. 90 (1-2), 88-94.

Wang, C., Zou, X., Gao, J., Zhao, Y., Yu, W., Li, Y., Song, Q., 2016. Pollution status of polycyclic aromatic hydrocarbons in surface sediments from the Yangtze River Estuary and its adjacent coastal zone. Chemosphere 162, 80-90.

Wang, M., Wang, C., Li, Y., 2017. Petroleum hydrocarbons in a water-sediment system from Yellow River estuary and adjacent coastal area, China: distribution pattern, risk assessment and sources. Mar. Pollut. Bull. 122 (1-2), 139-148.

Wu, Y., Zhang, J., Mi, T.-Z., Li, B., 2001. Occurrence of n-alkanes and polycyclic aromatic hydrocarbons in the core sediments of the Yellow Sea. Mar. Chem. 76, 1-15.

Yunker, M.B., Macdonald, R.W., Vingarzan, R., Mitchell, R.H., Goyette, D., Sylvestre, S., 2002. PAHs in the Fraser River basin: a critical appraisal of PAH ratios as indicators of PAH source and composition. Org. Geochem. 33 (4), 489-515.
Yu, W., Liu, R., Xu, F., Men, C., Shen, Z., 2016. Identifications and seasonal variations of sources of polycyclic aromatic hydrocarbons (PAHs) in the Yangtze River Estuary, China. Mar. Pollut. Bull. 104 (1-2), 347-354.

Zhang, J., Wu, Y., Jennerjahn, T.C., Ittekkot, V., He, Q., 2007. Distribution of organic matte in the Changjiang (Yangtze River) Estuary and their stable carbon and nitrogen isotopic ratios: implications for source discrimination and sedimentary dynamics. Mar. Chem. 106 (1-2), 111-126.

Zhang, P., Song, J.M., Yuan, H.M., 2009. Persistent organic pollutant residues in the sediments and mollusks from the Bohai Sea coastal areas, North China: an overview. Environ. Int. 35, 632-646.

Zhang, J., Mauzerall, D.L., Zhu, T., Liang, S., Ezzati, M., Remais, J.V., 2010. Environmenta health in China: progress towards clean air and safe water. Lancet 375 (9720), 1110-1119.

Zhang, J.D., Wang, Y.S., Cheng, H., Jiang, Z.Y., Sun, C.C., Wu, M.L., 2015. Distribution and sources of the polycyclic aromatic hydrocarbons in the sediments of the Pearl River estuary, China. Ecotoxicology 24 (7-8), 1643-1649.

Zhao, Z., Tang, J., Xie, Z., Chen, Y., Pan, X., Zhong, G., et al., 2013. Perfluoroalkyl acids (PFAAs) in riverine and coastal sediments of Laizhou Bay, North China. Sci. Total Environ. 447 (1), 415-423.

Zheng, G.J., Richardson, B.J., 1999. Petroleum hydrocarbons and polycyclic aromatic hydrocarbons (pahs) in Hong Kong marine sediments. Chemosphere 38 (11) 2625-2632.

Zhong, G., Tang, J., Zhao, Z., Pan, X., Chen, Y., Li, J., et al., 2011. Organochlorine pesticides in sediments of Laizhou Bay and its adjacent rivers, North China. Mar. Pollut. Bull. 62 (11), 2543-2547. 